\title{
SUPPLY LINE ENGINEERING ON IMPORTATION AND EXPORTATION: BIMSTEC PERSPECTIVE
}

\author{
Arodh Lal KARN ${ }^{1}$, Rakshha Kumari KARNA ${ }^{2}$ \\ ${ }^{1}$ School of Management, Northwestern Polytechnical University, Youyi road, 710072, Xi'an, China \\ ${ }^{2}$ School of Management, Harbin Institute of Technology, Nangang str., 150001, Harbin, China \\ ${ }^{*}$ E-mail: alkmaithili@nwpu.edu.cn
}

\begin{abstract}
Purpose - the purpose of this paper is to investigate whether supply line engineering strategies of goods and service exports, exports transport services and export time have a significant impact on GDP growth of BIMSTEC countries or not.
\end{abstract}

Research methodology - the study employed a panel vector error correction model (VECM) instead of loose VAR to examine the short and long-run relationship among the selected indicators and GDP growth.

Findings - in the long-run, the time of export negatively and suggestively associate with GDP. Conversely, VECM based Granger causality test signposted that in short-run only unidirectional causality running from goods and service exports (GSE), trade duration like exports time (ET) toward GDP and for the rest of the variables no causality found.

Research limitations - this study is contextualized only on Bangladesh, Bhutan, India, Myanmar, Nepal, Sri Lanka and Thailand.

Practical implications - to investigate the current position of the link between supply line logistics strategies and economic growth by using annual data for the period of 1980 to 2014 and possible weaknesses and logistics presence.

Originality/Value - this paper is an attempt, first of its kind, to fill up this shortfall, to estimate the relationship of exports transport services, exports time, and goods and services exports with GDP growth of BIMSTEC countries.

Keywords: Logistics Strategies, Lead time, Import, Export, South Asian Countries, GDP Growth, Penal Data, VECM Model.

JEL Classification: M20, R40, R41.

Conference topic: Contemporary Issues in Economics Engineering.

\section{Introduction}

Import and export is a cautious dynamic factor that controls the growth of GDP in any country. In addition to import and export trade, the transportation industry is also a dominant factor and may have an encouraging relationship with the development of GDP. Therefore, to be close to the international market, we must first have decent transportation and related logistics services (Scott \& Storper, 2015). As China's economy seems to have declined slightly, the world regards South Asia as its economic centre because of its impressive growth potential. The subregional group BIMSTEC has been in existence for 20 years, but the results of such regional cooperation are rarely felt "Towards a Peaceful, Prosperous and Sustainable Bay of Bengal Region". It is important to check possible weaknesses and logistics presence in this reason for a clear understanding of the picture for managerial implications and in perspective of government policy makings.

The economic growth substantiated by exports has been widely explored in context to North America (Rouquet \& Vauché, 2015; Daugherty, Bolumole, \& Grawe, 2019) and Europe (Ülkü, 2012; Bendoly, Craig, \& DeHoratius, 2018) and have been studied in a number of earlier studies. Similar studies have focused on logistics issues in Bulgaria (Sanchis-Pedregosa, Machuca, \& Gonzalez-Zamora, 2018), South Africa (Stank, Pellathy, In, Mollenkopf, \& Bell, 2017), Australia (Baker, Merkert, \& Kamruzzaman, 2015), Korea (Hansen \& Grunow, 2015), Asia Pacific (Narayana, Pati, \& Vrat, 2014). These countries have availed large benefits of transportations and logistics (T\&L) services over the last few years. However, to date, there has been no comprehensive study reported in the literature that has focused on BIMSTEC. Yet there are many isolated examples of the individual nation-state and their respective logistics capabilities of Asia. So far, one of these studies has focused on air transport and economic progress in SAARC countries. 
(Hakim \& Merkert, 2016), suggesting a further research space for logistics variables and economic progress in South Asian countries. Hence, this study is an attempt, first of its kind, to project the correlation of transportation services of exports, time to exports, and exports of goods and services with GDP growth of BIMSTEC realms. This study is contextualized on the BIMSTEC region.

The rest of research paper structured is as follows: the next section of the study is consisting of a literature review of the previous studies; section 3 explains econometrical methodology and data sources in detail; while chapter 4 and 5 describing results and conclusion.

\section{Literature review}

Supply line engineering needs to implement logistics strategy effectively. It turns out that there is a strong relationship between transportation and logistics (T\&L) and economic growth (GDP), According to Baker et al. (2015), the direction of causality is still unclear. At present, only a small amount of causal analysis has been carried out in the field of logistics. According to He, Chen, Liu, and Guo (2017), logistics strategy refers to reengineering all policies that facilitate the flow of materials, information, and capital between merchants and patrons. Supply line engineering related activities include customer response, inventory management, supply, transportation and warehousing along with technological advancements. These strategies allow the company to adopt the most cost-effective goods distribution methods (Blonigen, \& Cristea, 2015).

In addition, global trade (exports/imports) is affected by time in two esteems. First of all, it impacts the choice of an overseas market to import or not to import. If entered, then secondly, time governs the trade volume (Hummels $\&$ Schaur, 2013). Mohamed (2015) studied the role of information communication technology (ICT) in shortening international trade time. By adopting a two-stage least square method on 16 Arab countries, he established a negative correlation between time and economic development. According to Schmidt-Eisenlohr (2013) deferrals in supply line engineering may occur due to lengthy export and import measures, select of transportation and custom clearance procedures.

Ehinomen and Daniel (2012) studied the long-term and causal relationship between Africa's exports and supply line strategies. They found the one-way causality from export to economic growth integration relation through autoregressive distributed lags (ARDL) method. Another research by Hu, Xiao, Deng, Xiao, and Wang (2015) further found that there was a two-way similarity between GDP and export using heterogeneous panel model. The causal relationship between real GDP, inward FDI and LDCs' real exports was studied over the period 1985 to 2014 by Ee (2016). His results reveal the causal relationship between Sierra Leone, Rwanda and Haiti's exports and real GDP, whereas Chad, Angola and Zambia results are in the opposite direction.

Methodologically interesting to our paper, Hidalgo-Gallego and Mateo-Mantecón (2019) used a Stochastic Frontier Analysis (SFA) to measure the effect of supply line engineering on airline market concentration on airport technical efficiency. Their study found concentration has a positive impact on supply line engineering and technical efficiency. Concentration positive effect on efficiency decreases when the level of concentration grows. For Asia, Park and Ha (2006) reviewed the Korean market and observed the inverse correlation between export demand and roadways logistic infrastructure. On this basis, Chang (2012) estimates parametric linear and non-parametric regression tree models based on Asia-Pacific Economic Cooperation APEC regional transport data for 2006 and 2007 and shows that this distance is related to demand, GDP, per capita income, population growth, and employment rate.

Setting the scene for this paper, when it comes to causality between economic growth (GDP) and supply line strategies, Küçükönal and Sedefoğlu (2017) observed clear differences between low-income countries to high and medium-income countries between the year of 2000 and 2013. Contrary to previous literature, they found that the oneway causal relationship from GDP to export demand only. Button and Yuan (2013) applied Time Series Cross Section (TSCS) study to check the causal relationship between export demand and GDP across 32 cosmopolitan areas in the United States. Van De Vijver, Derudder and Witlox (2014) studied interconnection between supply line strategies and transportation by relating mixed TSCS Granger causality tests to a number of Asia-Pacific country-pairs. As with Wolfe, Malina, Barrett and Waitz (2016) they based their TSCS analysis on F-statistics and did not test the short-run and long-run aspects of causal relationships.

In a final step, we follow a panel vector error correction model to examine the short and long-run relationship among the selected indicators and GDP growth. For studying time as an international trade barrier, the most important major three aspects of time are Just-in-time, lead time and time variation. Choice of transportation, length of time and route type are the factors that affect it. These factors determine the market to enter and volume to trade in international trade, therefore it has important implications on economic growth.

Based on the background study, the following hypotheses are proposed:

$\mathrm{H}_{1}$ : There is a substantial short-run and long-run relationship among supply line strategy (exports of goods and services) and GDP of BIMSTEC Nations.

$\mathrm{H}_{2}$ : There is a considerable short-run and long-run correlation between supply line strategy (exports time) and GDP of BIMSTEC Nations. 
$\mathrm{H}_{3}$ : There is an important short-run and the long-run association between supply line strategy (exports transport services) and GDP of BIMSTEC Nations.

\section{Data gathering and methods}

Here in this regard, we strive to use the annual data from 1980 to 2014 to identify the links between supply line engineering logistics and economic growth (GDP). Facts and data on the BIMSTEC States were collected from World Development Indicator (WDI). The data for goods and services exports (GSE in constant 2010 US\$), export transport services (ETS of commercial service exports), export time in days (ET) and GDP per capita (GDP in constant 2010 US\$) were used to estimate the causal relationships. The descriptive statistics of variables that were used for this study are as follows (also see Table 1).

Table 1. Descriptive statistics

\begin{tabular}{|c|c|c|c|c|}
\hline & LnGDP & LnGSE & LnET & LnETS \\
\hline Mean & 6.392535 & 8.271869 & 2.953283 & 3.325500 \\
\hline Median & 6.635734 & 6.999999 & 3.220077 & 3.435275 \\
\hline Maximum & 8.091657 & 25.42299 & 3.444947 & 4.212485 \\
\hline Minimum & 1.007868 & 0.000000 & 1.989894 & 2.100337 \\
\hline Std. Dev. & 1.133999 & 4.911781 & 0.562653 & 0.549032 \\
\hline Skewness & -2.374422 & 1.192699 & -0.993181 & -0.276446 \\
\hline Kurtosis & 9.655001 & 3.606918 & 2.245651 & 1.763021 \\
\hline Jarque-Bera & 4659.6304 & 40.39979 & 29.01008 & 12.46229 \\
\hline Probability & 0.000000 & 0.000000 & 0.000000 & 0.001879 \\
\hline
\end{tabular}

Note: All variables are presented in natural logarithms. Bhutan has missing observations for a small number of years, which results in the overall series being an unbalanced panel.

In order to balance the large standard deviations of similar samples and to induce stationarity in covariance and variance matrices, the variables were converted into natural logarithms. The study employed a panel vector error correction model to examine short and long-run relationship among the selected indicators and GDP growth, as followings:

$$
\ln G D P_{i t}=\beta_{0}+\beta_{1}\left(\ln G S E_{i t}\right)+\beta_{2}\left(\ln E T_{i t}\right)+\beta_{3}\left(\ln E T S_{i t}\right)+\mu_{i t},
$$

GDP = Gross domestic product

$G S E=$ goods and service exports

ET = Export time

ETS $=$ Exports Transport services

$\beta_{1}, \beta_{2}=$ sloops of coefficients $i=$ Country in the panel

$t=$ Time period

$\mu=$ Error term

$\ln =$ refers to $\log$

\subsection{Unit root test}

First, a panel unit root test is applied on economic theory which suggests that the past and present are not influenced by the future, whereas, the past can be on the basis of the future or the present (Granger, 1969). The panel dataset for South Asian states are not sturdily well-adjusted and since South Asian nations are heterogeneous in nature, this study uses the method for the panel unit root test (Im, Pesaran, \& Shin, 2003). There are different methods available to check stationarity of series but each method has few deficiencies, there are two panel unit root tests i.e. Levin, Lin and Chu (LLC) (Levin, Lin, \& Chu, 2002) and Im, Pesaran and Shin (IPS), (Im et al., 2003). We applied these tests on the basis of more significance over others. The main advantage of applying LLC test to check the heterogeneity among different cross sections is that in the occurrence of serial correlation and few sample size LLC have very serial correlation and low power among each other. Therefore, to address on evacuating serial correlation and LLC confinements, we also applied Im, Pesaran and Shin test which additions to check heterogeneity and equality productive like we have a few sample size, this test reduces serial correlation too.

Our tests are based on the following equation.

$$
\Delta x_{i t}=\alpha_{i}+\beta x_{i, t-1}+\sum_{j=1}^{p i} \beta_{i j} \Delta x_{i, t-j}+\mu_{i t} .
$$


Whereas $i=1, \ldots, \mathrm{I}$ is used as a representor of countries, $t=1, \ldots, \mathrm{T}$ is used as a representor of time and $x_{i, t}$ is used as a representor for countries $i$ over the time period $t$. The optimal lags represents here by $p i$ and for residuals used $\mu_{i t}$. Levin, Lin and Chu (LLC) test has a null hypothesis $H 0: \beta=0$ opposing to the alternative $H 1: \beta<0$. While, IPS test is based on Eq. (1), But in IPS $\beta$ can be varied. The IPS test is better than that of LLC test because of the heterogeneity between the coefficients of $\beta$ for all the panel units. The IPS test has a null hypothesis $H_{0}: \beta_{1}=0 \forall \mathrm{i}$, and alternate hypothesis for the IPS test is $H_{0}: \beta_{1}<0 \forall I$.

\subsection{Panel co-integration test}

In the second step, all series under investigation (goods and services exports, goods and services imports, transport services exports, transport services import, time to export in days, time to import in days and economic growth) are tested for panel co-integration with the same order to establish the long-run relationships among variables. we apply penal co-integration and formulate a model as follows as Eq. (3).

$$
y_{i t}=\beta_{1}+p_{i} t+\beta_{1 i} x_{1 . i t}+\beta_{2 i} x_{2 . i t}+\beta_{3 i} x_{3 . i t} \ldots \ldots \ldots \ldots \ldots \ldots . . . \ldots+\varepsilon_{i t} .
$$

Whereas $i=1, \ldots$,I used as the representation of the countries, $t=1, \ldots, \mathrm{T}$ reference to the time period, in equation $\beta_{1}$ shows intercept and $p_{i}$ arrogant trend specially for every nation respectively.

\subsection{Vector Error Correction Model (Panel VECM)}

The results of these co-integration tests determine the type of causality tests will be then used in the next subsequent step. In this third step, if the series are co-integrated of the same order, the vector error correction model (VECM) is applied to find long-run and short-run relationships. To offset the false result and catering for the important information that has been lost, the most current systems of panel co-integration and panel VECM were used as part of this research paper. Hence, to check the imbalance, the model was firstly given by (Bai \& Perron, 2003). It has already been discussed that our all variables are constant at 1 (I), so, cointegration is also possible. Therefore, panel VECM is the right model to further investigate both short-run and long-run correction model VECM instead of loose VAR. The VECM is confined by VAR model where the restraint power is the existing of the long-run link among the variables. The next is the equation of the panel VECM mol.

$$
\begin{aligned}
& \Delta \operatorname{lngdp_{it}}=\alpha_{1 j}+\sum_{\mathrm{K}=1}^{m} \alpha_{11 i k} \Delta \operatorname{lngdp}_{i t_{-} k}+\sum_{\mathrm{K}=1}^{m} \alpha_{12 i k} \Delta \operatorname{lnggs}_{i t_{-} k}+\sum_{\mathrm{K}=1}^{m} \alpha_{13 i k} \Delta \operatorname{lnte}_{i t_{-} k}+\sum_{\mathrm{K}=1}^{m} \alpha_{14 i k} \Delta \operatorname{lntse}_{i t_{-} k}+\lambda_{1 t} \mathrm{ECT}_{1 i t_{-} 1}+\mu_{1 i t} ; \\
& \operatorname{negs}_{i t}=\alpha_{1 j}+\sum_{\mathrm{K}=1}^{m} \alpha_{11 i k} \Delta \operatorname{lngdp_{it_{-}k}}+\sum_{\mathrm{K}=1}^{m} \alpha_{12 i k} \Delta \operatorname{lnegs}_{i t_{-} k}+\sum_{\mathrm{K}=1}^{m} \alpha_{13 i k} \Delta \operatorname{lnte}_{i t_{-} k}+\sum_{\mathrm{K}=1}^{m} \alpha_{14 i k} \Delta \operatorname{lntse}_{i t_{-} k}+\lambda_{1 t} \mathrm{ECT}_{1 i t_{-} 1}+\mu_{1 i t}
\end{aligned}
$$

$\Delta \operatorname{lnte}_{i t}=\alpha_{1 j}+\sum_{\mathrm{K}=1}^{m} \alpha_{21 i k} \Delta \operatorname{lngdp_{it_{-}k}}+\sum_{\mathrm{K}=1}^{m} \alpha_{22 i k} \Delta \operatorname{lnggs}_{i t_{-} k}+\sum_{\mathrm{K}=1}^{m} \alpha_{23 i k} \Delta \operatorname{lnte}_{i t_{-} k}+\sum_{\mathrm{K}=1}^{m} \alpha_{24 i k} \Delta \operatorname{lntse}_{i t_{-} k}+\lambda_{1 t} \mathrm{ECT}_{1 i t_{-} 1}+\mu_{1 i t} ;$

$\Delta \operatorname{lntse}_{i t}=\alpha_{1 j}+\sum_{\mathrm{K}=1}^{m} \alpha_{31 i k} \Delta \operatorname{lngdp_{it_{-}k}}+\sum_{\mathrm{K}=1}^{m} \alpha_{32 i k} \Delta \operatorname{lnegs}_{i t_{-} k}+\sum_{\mathrm{K}=1}^{m} \alpha_{33 i k} \Delta \operatorname{lnte}_{i t_{-} k}+\sum_{\mathrm{K}=1}^{m} \alpha_{34 i k} \Delta \operatorname{lntse}_{i t_{-} k}+\lambda_{1 t} \mathrm{ECT}_{1 i_{-}{ }^{1}}+\mu_{1 i t}$.

Here $\Delta$ stands for the first difference, $\mathrm{K}$ means maximum lags distance on the base of SIC. The observation of Eq. (4a) limits us to the short-run and long-run one-way relationship. For instance, a longer run exports result in the price of stock index volatility but in other instance, all the coefficients of $\alpha_{12 \mathrm{IK}}$ are equal to zero for Eq. (4a). However, for reverse checking of causality, the index volatility does not Granger causes exports and all the coefficients of $\alpha_{22 \mathrm{iK}}$ are equal to zero. As regards the short term causality, the remaining variable may be tested in the same method. Lastly, the current situation of long and short-run causality test along the significance of t-test on coefficients of $\lambda$ error correction term ECTit.

\subsection{Granger causality test}

We also used bivariate Granger causality to check the lead-lag link among the stock price index vaporization and macro-economic variables for growth and merging major economics. Granger (1969) gave special meaning to causality 
by showing if a variable $Y_{t}$ can be predicted by using the past session of variable $X_{t}$, then $X_{t}$ is said to cause $Y_{t}$ and the conversely. Therefore, the pilot equations are assessed to unfold any short-run causal links along the Granger causality analysis at the stock price index and any of the macro-economic variables separately.

$$
\begin{gathered}
Y_{t}=\beta_{0}+\sum_{j=1}^{n} \beta_{1 j} Y_{t-1}+\sum_{h=1}^{p} \beta_{2 h} X_{t-p}+\varepsilon_{1 t} \\
X_{t}=\alpha_{0}+\sum_{s=1}^{k} \alpha_{1 s} X_{t-s}+\sum_{t=1}^{m} \alpha_{2 t} X_{t-m}+\varepsilon_{2 t} .
\end{gathered}
$$

Here $t$ represents time, economic growth is being represented with $Y_{t}$, while $X_{t}$ represents all independent variables over time, lags of GDP are shown with $X_{t-j} \& X_{t-m}$, while lags of all independent variables are shown though $X_{t-p}$ $\& X_{t-s}$ and $\varepsilon_{1 t} \& \varepsilon_{2 t}$ for time $t$ are white noise vector.

\section{Results of the research}

This study engaged panel VECM model to inspect long and short-run causality within proposed variables. Nevertheless, beforehand panel VECM, panel unit root is being exploited in order to check the order of integration among series. Table 2 denotes the effects of IPS and LLC of unit root tests, which is at the level and first difference. Based on the findings of the LLC and IPS, it is detected that all the constraints (GDP, GSE, ET and ETS) at level exhibits nonstationary however all variables befitted stationary at first difference.

Table 2. Data stationary test

\begin{tabular}{|c|c|c|c|cc|c|}
\hline \multirow{2}{*}{ Constructs } & \multicolumn{2}{|c|}{ Levin-Lin-Chu unit root test (LLC) } & \multicolumn{2}{|c|}{ Im-Pesaran-Shin unit root test (IPS) } & Result \\
\cline { 2 - 7 } & Level & First difference & Level & First Difference & \\
\hline $\ln G D P$ & $0.660(0.745)$ & $-5.460 \quad(0.000)$ & $1.618(0.942)$ & -9.107 & $(0.000)$ & I(1) \\
\hline $\ln G S E$ & $0.003(0.501)$ & $-4.343(0.000)$ & $0.601(0.161)$ & -9.703 & $(0.000)$ & $\mathbf{I}(1)$ \\
\hline $\ln E T$ & $0.447(0.672)$ & $-4.947 \quad(0.005)$ & $-1.344(0.089)$ & -4.236 & $(0.000)$ & $\mathbf{I}(1)$ \\
\hline $\ln E T S$ & $-1.414(0.079)$ & $-6.647(0.005)$ & $-1.534(0.064)$ & -4.177 & $(0.000)$ & $\mathbf{I}(1)$ \\
\hline
\end{tabular}

Table 3. Panel co-integration test (KAO co-integration test)

\begin{tabular}{|l|l|l|l|l|}
\hline & & & t-Statistic & Prob. \\
\hline ADF & & & 2.707658 & 0.0047 \\
\hline \multicolumn{2}{|c|}{ Residual variance } & 1.984011 & \\
\hline \multicolumn{2}{|c|}{ HAC variance } & 0.100404 & \\
\hline \multicolumn{2}{|c|}{ Null Hypothesis: There is no co-integration } \\
\hline
\end{tabular}

Table 4. Johansen fisher panel co-integration test

\begin{tabular}{|c|c|c|c|c|}
\hline Hypothesized & Fisher Stat.* $^{*}$ & & Fisher Stat.* $^{*}$ & \\
\hline No. of CE(s) & (trace test) & Probability & (max-Eigen test) & Probability \\
\hline None & 39.02 & 0.0000 & 25.50 & 0.0029 \\
\hline At most 1 & 18.08 & 0.0062 & 16.50 & 0.0205 \\
\hline At most 2 & 6.900 & 0.4006 & 8.030 & 0.2499 \\
\hline At most 3 & 2.451 & 0.8804 & 2.507 & 0.8804 \\
\hline
\end{tabular}


The subsequent approach after proving the stationarity of variables was to exam the presence of long term association between the variables in the model. The research at hand engaged two co-integration tests, one is a residual based test called KAO panel co-integration test, which only recognizes the presence of co-integration and other is Johnsen fisher panel co-integration test, a maximum-likelihood-based test, which explains about a number of co-integration as well no co-integration with the null hypothesis. The null hypothesis of no co-integration (Table 3) is rejected by the results of the panel co-integration tests in Table 4, which implicated that there is a long way correlation among $\ln \mathrm{GSE}, \ln \mathrm{ET}, \ln \mathrm{ETS}$ and $\ln \mathrm{GDP}$.

Table 5. Normalized long-run relationship of VECM

\begin{tabular}{|l|c|c|c|}
\hline \multicolumn{1}{|c|}{ Variables } & Coefficients & Standard errors & T-value \\
\hline InGSE & 0.0654 & 3.0219 & 2.3001 \\
\hline InET & -0.5001 & 0.2631 & -1.9611 \\
\hline InETS & 0.9702 & 0.2582 & 3.7799 \\
\hline C & -0.7119 & 4.0219 & -6.7071 \\
\hline CointEq1 & $\mathbf{0 . 4 3}$ & 0.1059 \\
\hline Adjusted R-squared & $\mathbf{2 3 . 0 0 9}$ & \\
\hline F-statistic & $\mathbf{0 . 6 0 0 1}$ & \\
\cline { 1 - 3 } Serial correlation LM (prob.) & $\mathbf{0 . 6 9 4}$ & \\
\hline Heteroscedasticity (prob.) &
\end{tabular}

Panel VECM model can only proceed if certain of its preconditions are fulfilled i.e. variables must be stationary at first difference and there should also be co-integration among purposed variables. Table 5 is the consequences of long-run associations among GSE, ET, ETS and GDP. Observed findings are signifying that there is a considerate and momentous relationship between $\ln$ EGS and $\ln$ GDP at $5 \%$ level of significance and can be understood like a $1 \%$ surge in $\ln \mathrm{EGS}$ upsurges $\ln \mathrm{GDP}$ by $6.54 \%$. The outcomes also showed that there is a reassuring and weighty correlation between $\ln$ TSE and $\ln$ GDP at $5 \%$ level of significance which indicates that $1 \%$ surge in $\ln$ TSE leads to an upsurge in $\ln$ GDP by $97 \%$. Nonetheless, the research also found the negative and significant bond between $\ln \mathrm{ET}$ and $\ln$ GDP but $10 \%$ level of significance, it means $1 \%$ surge in $\ln$ ET leads to fall $\ln$ GDP by $50 \%$.

Finally, Table 6 presents statistics for the error correction term, the error correction term of the coefficient $(-0.7119)$ is significant at $1 \%$ significance level. There is a highly significant and negative symbol of the error correction term which re-implemented the appearance of a long-run relationship among the variables. However, the time taken for re-adjustment from previous year dis-equilibrium to create value added in current year equilibrium is only $71 \%$.

Furthermore, R-square value is indicating that $43 \%$ disparity independent variability is due to projected variations while $56 \%$ variation is due to other variables/factors which are not a part of the current model and F-statistics value is showing that the overall model is a good fit.

Table 6. VECM based Granger Causality Test: for BIMSTEC Countries

\begin{tabular}{|l|c|c|c|}
\hline \multicolumn{1}{|c|}{ Null Hypothesis: } & Obs. & F-Statistic & Prob. \\
\hline LnGSE doesn't Granger Cause LnGDP & 171 & 9.67810 & 0.0023 \\
\hline LnGDP doesn't Granger Cause LnGSE & & 2.150010 & 0.1432 \\
\hline LnET doesn't Granger Cause LnGDP & 169 & 0.38113 & 0.5378 \\
\hline LnGDP doesn't Granger Cause LnET & 153 & 0.00578 & 0.9390 \\
\hline LnETS doesn't Granger Cause LnGDP & & 11.2534 & 0.0011 \\
\hline LnGDP doesn't Granger Cause LnETS & 0.43204 & 0.5020 \\
\hline
\end{tabular}

Table 6 reports the results of causal direction between projected variables. The findings showed a unidirectional causality running from $\ln \mathrm{GSE}$ and $\ln$ ETS $\operatorname{lnGDP}$. It implies that $\operatorname{lnGDP}$ will effect due to changes in $\ln$ GSE and $\ln$ ETS in the short-run. On the other side, there is no proof of causality between $\ln$ ET and $\ln$ GDP in short-run for BIMSTEC nations. 
Response to Generalized One S.D. Innovations

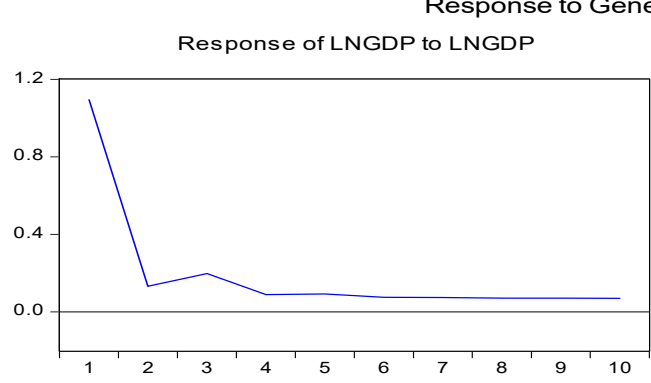

Response of LNGDP to LNEGS
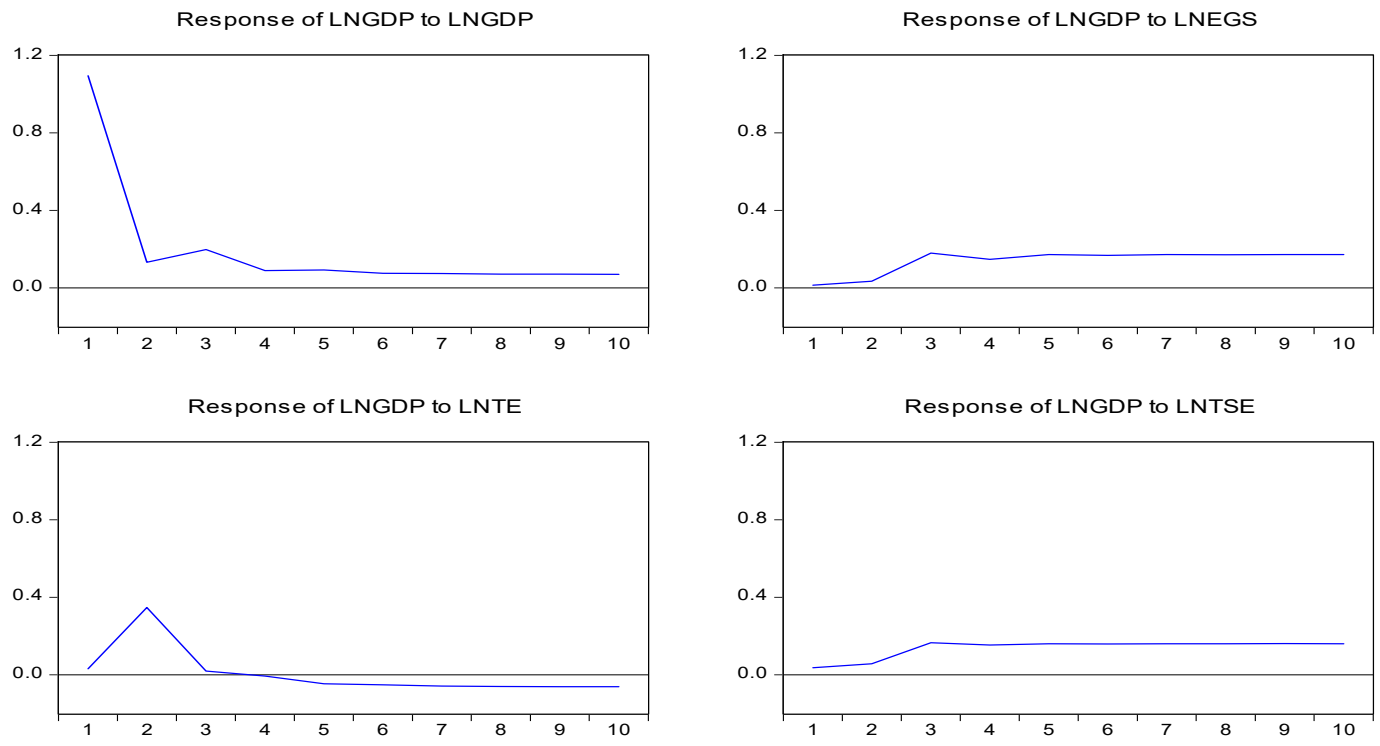

Figure 1. Impulse Response Functions

We adopted the following order to conduction IRF analysis for $\ln \mathrm{GDP}, \ln \mathrm{GSE}, \ln \mathrm{ET}$ and $\ln \mathrm{ETS}$. The above graphical presentation in Figure 1 indicates the response of economic growth due to shock in $\ln \mathrm{GSE}, \ln \mathrm{ET}, \ln \mathrm{ETS}$ and $\ln$ GDP itself. To interpret the impulse response functions, one needs to clearly understand what impulse response is. The Impulsive reactions is mainly to the adverse effects of variable substitution variables. The disturbing pulses are calculated as the change in the standard deviation of the variation. Like, if a variable is changed from 1 item of standard deviation and then in response to what happens to the variable. This response is then over time, if the response back to zero level line, we can say the response is temporary and will disappear in a given period of time, so the response converges the zero line. If the zero line responses, then it can be commented on the impact of having a non-convergent and non-time response to shocks. Whether it is going to produce a temporary impact by observing the impact of policies or a longer period of time and longer cumulative effect, change the pattern of economic changes which will be related to theory.

One standard shock to $\ln$ GDP indicates that $\ln$ GDP will respond positively for the next ten periods but the very sudden decreasing response for the first period after this respond systematically. When the impulse is $\ln$ GSE and $\ln$ ETS then for the $\ln$ GDP responded positively for the next ten years. However, due to one standard deviation shock to $\ln E T$ shows that for the first three periods $\ln$ GDP responds positively but for the last seven years, $\ln$ GDP responds negatively.

Table 7. Variance decomposition analysis

\begin{tabular}{|c|c|c|c|c|c|}
\hline Period & S.E. & LnGDP & LnGSE & LnET & LnETS \\
\hline 1 & 1.094100 & 100.0000 & 0.000000 & 0.000000 & 0.000000 \\
\hline 2 & 1.158920 & 89.44211 & 0.079902 & 8.728703 & 0.744224 \\
\hline 3 & 1.200518 & 86.01710 & 2.256002 & 8.093388 & 2.585388 \\
\hline 4 & 1.222501 & 83.44699 & 3.620016 & 7.877920 & 4.066906 \\
\hline 5 & 1.248869 & 82.46744 & 5.350063 & 7.635636 & 5.4502132 \\
\hline 6 & 1.273071 & 77.74769 & 6.869762 & 7.700070 & 6.720050 \\
\hline 7 & 1.247676 & 77.00040 & 8.410385 & 7.650402 & 7.798427 \\
\hline 8 & 1.281658 & 74.54376 & 9.610184 & 7.643416 & 8.977320 \\
\hline 9 & 1.305343 & 72.00057 & 11.00006 & 7.644334 & 8.982538 \\
\hline 10 & 1.318601 & 69.24094 & 12.19922 & 7.651101 & 10.90074 \\
\hline \multicolumn{7}{|c|}{ Cholesky Ordering: LNGDP LNGSE LNET LNETS } \\
\hline
\end{tabular}

Table 7 reports the results of variance decomposition that in GDP, 100\% attribute that its increase or decrease to its own specify shock instead any other variable projected in the model. The findings are indicating that $\ln \mathrm{ET}$ is the only variable which can be considered in explaining the forecast error variance which accounts for $8 \%$. However, $\ln \mathrm{GSE}$ and $\ln \mathrm{ETS}$ only contributes $2.2 \%$ and $2.5 \%$ to forecast error variance. However, from period seven to onward, 
$\ln$ EGS contributes $8.4 \%, 11 \%$ and $12 \%$ whereas $\ln$ ETS $7.7 \%, 8.9 \%$ and $10.9 \%$. It implies that $\ln$ GDP is more determined for the first 6 years by $\ln \mathrm{ET}$ but for the next four years, $\ln \mathrm{GSE}$ and $\ln \mathrm{ETS}$ replace $\ln \mathrm{ET}$ as the leading factor to determine economic growth.

\section{Discussion and conclusion}

The study at hand examined the causal relationship among goods and services export (GSE), export time (ET), export transport services (ETS) and GDP growth (GDP). Panel Time series data is being utilized from the BIMSTEC economies from 1980 to 2014. Furthermore, to examine the long-run and short-run causality, panel vector error correction (Panel VECM) model is employed. The findings of the study showed a positive and significant long-run relationship among $\ln \mathrm{GSE}, \ln \mathrm{ETS}$ and $\ln \mathrm{GDP}$. On the other hand, $\ln$ ET negatively and significantly associated with $\ln$ GDP in the long-run. However, VECM based Granger causality test indicated that only unidirectional causality running from lnGSE to lnETS towards lnGDP in the short-run and for the rest no causality. In contrast to previous studies, we don't find a bi-directional relationship between supply line strategies of goods and services exports and economic growth, which confirms our hypothesis.

This is a very significant finding for the corresponding departments like developers, government, support staff, airports, seaports, cargo agents, transport planners of BIMSTEC countries for implications. The growth of the average economic region of $6 \%$ per year and increasing for many years with the increase in disposable income per capita can be a rapid increase in the vicinity of the Plan, stakeholders also have to overcome the supply line engineering infrastructure of the logistics, planning and secure investment and the predictor can improve transportation needs. There is a clear relationship between transportation and levels of development. We have noted that all BIMSTEC countries have not fully converted to the desired level of development. The policy implications are for the airlines, government, logistics companies' freight forwarders and planners in transpiration and civil aviation in BIMSTEC nations. All the policy stakeholders involved in the supply line of logistics should plan theory structure for meeting more demands for imports and exports along with reducing the lead times.

As a limitation of our analysis, we acknowledge that we were unable to account for all potentially relevant explanatory variables mainly due to a lack of data. Further studies could seek to incorporate other time-varying covariates (e.g. robust data on Globalization, foreign direct investment) in the analysis by using multivariate econometric frameworks that may yield more robust results. However, based on all the information that is available to us we are confident that the variables used in our models are good proxies, but future studies may want to extend the set of a variable once data becomes available. Our study is, therefore, the best we can do to update policymakers. It is likely that we have not acknowledged for all cultural, demographic, spatial or other factors that are specific to a nation-state.

\section{Reference}

Bai, J., \& Perron, P. (2003). Computation and analysis of multiple structural change models. Journal of Applied Econometrics, 18(1), 1-22. https://doi.org/10.1002/jae.659

Baker, D., Merkert, R., \& Kamruzzaman, M. (2015). Regional aviation and economic growth: cointegration and causality analysis in Australia. Journal of Transport Geography, 43, 140-150. https://doi.org/10.1016/j.jtrangeo.2015.02.001

Bendoly, E., Craig, N., \& DeHoratius, N. (2018). Consistency and recovery in retail supply chains. Journal of Business Logistics, 39(1), 26-37. https://doi.org/10.1016/j.ijpe.2011.09.015

Blonigen, B. A., \& Cristea, A. D. (2015). Air service and urban growth: Evidence from a quasi-natural policy experiment. Journal of Urban Economics, 86, 128-146. https://doi.org/10.1016/j.jtrangeo.2014.11.008

Button, K., \& Yuan, J. (2013). Airfreight transport and economic development: an examination of causality. Urban Studies, 50(2), 329-340. https://doi.org/10.1177/0042098012446999

Chang, L. Y. (2012). International air passenger flows between pairs of APEC countries: a non-parametric regression tree approach. Journal of Air Transport Management, 20, 4-6. https://doi.org/10.1016/j.jairtraman.2011.04.001

Daugherty, P. J., Bolumole, Y., \& Grawe, S. J. (2019). The new age of customer impatience: an agenda for reawakening logistics customer service research. International Journal of Physical Distribution \& Logistics Management, 49(1), 4-32. https://doi.org/10.1108/IJPDLM-03-2018-0143

Ee, C. Y. (2016). Export-led growth hypothesis: empirical evidence from selected Sub-Saharan African countries. Procedia Economics and Finance, 35, 232-240. https://doi.org/10.1016/S2212-5671(16)00029-0

Ehinomen, C., \& Daniel, O. O. (2012). Export and economic growth nexus in Nigeria. Management Science and Engineering, 6(4), 132. https://doi.org/10.3968/j.mse.1913035X20120604.1043

Granger, C. W. (1969). Investigating causal relations by econometric models and cross-spectral methods. Econometrica: Journal of the Econometric Society, 37(3), 424-438. https://doi.org/10.2307/1912791

Hakim, M. M., \& Merkert, R. (2016). The causal relationship between air transport and economic growth: Empirical evidence from South Asia. Journal of Transport Geography, 56, 120-127. https://doi.org/10.1016/j.jtrangeo.2016.09.006

Hansen, K. R. N., \& Grunow, M. (2015). Planning operations before market launch for balancing time-to-market and risks in pharmaceutical supply chains. International Journal of Production Economics, 161, 129-139. https://doi.org/10.1016/j.ijpe.2014.10.010 
He, Z., Chen, P., Liu, H., \& Guo, Z. (2017). Performance measurement system and strategies for developing low-carbon logistics: A case study in China. Journal of Cleaner Production, 156, 395-405. https://doi.org/10.1016/j.jclepro.2017.04.071

Hidalgo-Gallego, S., \& Mateo-Mantecón, I. (2019). Effect of concentration in airline market on Spanish airport technical efficiency. Journal of Air Transport Management, 76, 56-66. https://doi.org/10.1016/j.jairtraman.2019.02.003

Hu, Y., Xiao, J., Deng, Y., Xiao, Y., \& Wang, S. (2015). Domestic air passenger traffic and economic growth in China: Evidence from heterogeneous panel models. Journal of Air Transport Management, 42, 95-100. https://doi.org/10.1016/j.jairtraman.2014.09.003

Hummels, D. L., \& Schaur, G. (2013). Time as a trade barrier. The American Economic Review, 103(7), $2935-2959$. https://doi.org/10.1257/aer.103.7.2935

Im, K. S., Pesaran, M. H., \& Shin, Y. (2003). Testing for unit roots in heterogeneous panels. Journal of Econometrics, 115(1), 5374. https://doi.org/10.1016/S0304-4076(03)00092-7

Küçükönal, H., \& Sedefoğlu, G. (2017). The causality analysis of air transport and socio-economics factors: the case of OECD countries. Transportation Research Procedia, 28, 16-26. https://doi.org/10.1016/j.trpro.2017.12.164

Levin, A., Lin, C. F., \& Chu, C. S. J. (2002). Unit root tests in panel data: asymptotic and finite-sample properties. Journal of Econometrics, 108(1), 1-24. https://doi.org/10.1016/S0304-4076(01)00098-7

Mohamed, N. M. A. (2015). Time as a barrier to international trade and economic growth: The role of information and communication technology in reducing time cost. Arab Economic and Business Journal, 10(2), 139-152. https://doi.org/10.1016/j.aebj.2015.10.002.

Narayana, S. A., Pati, R. K., \& Vrat, P. (2014). Managerial research on the pharmaceutical supply chain - A critical review and some insights for future directions. Journal of Purchasing and Supply Management, 20(1), 18-40. https://doi.org/10.1016/j.pursup.2013.09.001

Park, Y., \& Ha, H. K. (2006). Analysis of the impact of high-speed railroad service on air transport demand. Transportation Research Part E: Logistics and Transportation Review, 42(2), 95-104. https://doi.org/10.1016/j.tre.2005.09.003

Rouquet, A., \& Vauché, L. (2015). A typology of logistics pooling in supply chains. Supply Chain Forum: An International Journal, 16(2), 2-12. https://doi.org/10.1080/16258312.2015.11673825

Sanchis-Pedregosa, C., Machuca, J. A., \& Gonzalez-Zamora, M. D. M. (2018). Determinants of success in transport services outsourcing: empirical study in Europe. The International Journal of Logistics Management, 29(1), 261-283. https://doi.org/10.1108/IJLM-09-2016-0207

Schmidt-Eisenlohr, T. (2013). Towards a theory of trade finance. Journal of International Economics, 91(1), 96-112. https://doi.org/10.1016/j.jinteco.2013.04.005

Scott, A. J., \& Storper, M. (2015). The nature of cities: the scope and limits of urban theory. International Journal of Urban and Regional Research, 39(1), 1-15. https://doi.org/10.1111/1468-2427.12134

Stank, T. P., Pellathy, D. A., In, J., Mollenkopf, D. A., \& Bell, J. E. (2017). New frontiers in logistics research: theorizing at the middle range. Journal of Business Logistics, 38(1), 6-17. https://doi.org/10.1111/jbl.12151

Ülkü, M. A. (2012). Dare to care: Shipment consolidation reduces not only costs, but also environmental damage. International Journal of Production Economics, 139(2), 438-446.

Van De Vijver, E., Derudder, B., \& Witlox, F. (2014). Exploring causality in trade and air passenger travel relationships: the case of Asia-Pacific, 1980-2010. Journal of Transport Geography, 34, 142-150. https://doi.org/10.1016/j.jtrangeo.2013.12.001

Wolfe, P. J., Malina, R., Barrett, S. R., \& Waitz, I. A. (2016). Costs and benefits of US aviation noise land-use policies. Transportation Research Part D: Transport and Environment, 44, 147-156. https://doi.org/10.1016/j.trd.2016.02.010 